\title{
Fiziksel ve Kimyasal Koşulların Çeşitli Yöntemlerle Elde Edilmiş Viral DNA’ya
}

Etkileri

\author{
Zeynep AKKUTAY-YOLDAR
}

Ankara Üniversitesi, Veteriner Fakültesi, Viroloji Anabilim Dalı, Dışkapı, 06110, Ankara, Türkiye.

Geliş Tarihi: 30.04.2018

Kabul Tarihi: 19.11.2018

\begin{abstract}
Özet: DNA virusları tamir mekanizmaları ve RNA viruslarına göre daha stabil olmaları sayesinde çevre şartlarına dirençli bir yapı gösterirler. Sahip oldukları bu direnç mutasyonel değişiklikleri elimine ederek, virusun korunmuş bölgelerinin kolaylıkla amplifikasyonu sağlamasına rağmen, uygun olmayan laboratuvar koşulları ve inhibe edici ajanlar, viral DNA tespitine engel olabilmektedir. Viral DNA eldesinde çeşitli yöntemlerin karşılaştırılmasının yapııdığı bu çalışmada aynı zamanda farklı fiziksel ve kimyasal koşulların viral nükleik asite olan etkileri de sorgulandı. Bu amaçla biri konvansiyonel metot olmak üzere toplam dört farklı ekstraksiyon yöntemi bir parapoxvirus olan ecythma contagiosumun DNA'sını tespit amacıyla kullanıldı. Elde edilen DNA'lar verimlilikleri yönünden kıyaslandıktan sonra çeşitli fiziksel (basınç, UV) ve kimyasal (deterjan) koşullara maruz bırakıldı. Basınçlı buhar otoklavına maruziyetten sonra viral DNA amplifikasyonu gerçekleşirken; tween 20 ve uv radyasyon viral DNA amplifikasyonu inhibe ettiler. Ticari kitlerin çoğu DNA ekstraksiyonunun süresini kısaltmaya yardımcı olurken konvansiyonel yöntem viral DNA tespiti açısından en yüksek verimliliği sağladı.
\end{abstract}

Anahtar Kelimeler: Ekstraksiyon, PCR, Viral DNA.

\section{The Effects of Physical and Chemical Conditions on Viral DNA Obtained by Various Methods}

\begin{abstract}
DNA viruses are more resistant to environmental conditions than RNA viruses due to their repair mechanisms and stablity of their genetic material. Despite these advantages, inadequate laboratory conditions and inhibitory agents can interfere with viral DNA detection. In this study, which compares various methods of viral DNA obtainment, the effects of different physical and chemical conditions on viral nucleic acid were also questioned. For this purpose, a total of four different extraction methods, one of which was the conventional method, have been used to detect the DNA of the parapox virus causing ecythma contagiosum. The isolated DNAs were exposed to various physical (pressure, uv) and chemical treatment (detergent) conditions before PCR amplification. While viral DNA amplification occured after exposure to autoclave pressure steam sterilizer; Tween 20 and UV radiation inhibited viral DNA amplification. While most commercial kits helped to shorten the duration of DNA extraction, the conventional method provided the highest efficiency for viral DNA detection.
\end{abstract}

Keywords: Extraction, PCR, viral DNA.

\section{Giriş}

Viruslar doğada insan, hayvan ve bitkileri enfekte edebilen, hatta el değmemiş buzulların içinde olmak üzere birçok farklı ve zorlu koşullara adapte olabilen ve enfekziyözitesini devam ettiren patojenlerdir (Zimmer, 2015). Sahip olduğu genetik materyale göre Deoksi Ribo Nükleik Asit (DNA) ve Ribo Nükleik Asit (RNA) olarak ikiye ayrılan viruslardan genetik materyalinde DNA içerenler çift sarmal yapıları sebebiyle bu koşullara daha dirençlidir. DNA içeren virus ailelerinden Poxviridae ailesi 375 kbç'ne varabilen genom ve morfolojik olarak kompleks simetriye sahip tuğla görünümü sergilemektedirler (Knowles, 2011). Poxviridae ailesi, Chordopoxvirinae ve Entomopoxvirinae olmak üzere iki alt aileye ayrılır. Parapoxvirus, Chordopoxvirinae alt ailesinde bulunan 11 cinsten birisidir. Bu cins; orf virus (ORFV), bovine papüler stomatit virus (BPSV), pseudocowpox virus (PCPV) ve Yeni Zelanda'da bulunan kırmızı geyiklerin parapoxvirusunu içermektedir (PVNZ) (Knowles, 2011; Skinner ve ark., 2012). Ailenin diğer üyelerinden farklı olarak Parapoxviruslar ovoid şekillidir. Koyun ve keçilerde orf hastalığına sebep olan bu virus meralarda aylarca canlılığını koruyabilmektedir (Murphy ve ark., 1999). Bu çalışmada çevre şartlarına dirençli olan orf virus DNA'sının farklı ekstraksiyon metotlarıyla eldesi sonrasında amplifikasyonlarının karşılaştırılması ve basınç, UV (Ultraviole) radyasyon ve deterjan gibi çeşitli kimyasal ve fiziksel faktörlere direncinin araştırılması hedeflenmiştir.

DNA virusları, proofreading mekanizmaları gereğince her ne kadar nükleotid hatalarını düzeltme ve stabilitelerini korumakta başarılı olsalarda, çeşitli etmenler sonucunda inhibe olabilmekte ve Polimeraz Zincir Reaksiyonunda (PCR) her zaman pozitif sonuç elde edilememektedir (Reha-Krantz, 2010; Wilson, 1997). Nükleik asitlerin amplifikasyonunun inhibe olabileceği aşamalardan birisi ekstraksiyondur. Tuzlar, deterjan ve fenollerin bu aşamada amplifikasyona engel olabileceği bilinmektedir (Arnal ve ark., 1999). PCR'ın etkin ve 
verimli bir şekilde çalışabilmesinde ekstraksiyon bir önkoşuldur. Ektraksiyon metotları virusun elde edildiği dokuya ve canlıya, göre değişiklik arz etmektedir. Gıdalarla bulaşan virusların tespitinde elüsyon-konsantrasyon, ultrafiltrasyon, ultrasantrifügasyon kullanılırken; dokudan ve kandan izole edilmesi planlanan viruslar için RNAzol, GTC-silica, nucleospin, magnetic beads gibi birçok farklı metot uygulanabilir (Arnal ve ark., 1999; Deng ve ark., 2005; Scherer ve ark., 2010). Bu çalışmada gerek konvansiyonel gerekse spin-kolon prensibiyle çalışan farklı firmalara ait ekstraksiyon yöntemlerinin nükleik ait amplifikasyonuna olan etkileri incelenmiştir. Bunu takiben de basınç, UV radyasyon ve tween 20 gibi çeşitli faktörlerin farklı koşullarda elde edilmiş olan viral DNA'ya etkisi araştırılmış ve bu ajanların varlığında farklı ekstraksiyon yöntemleriyle elde edilmiş viral DNA'nın ihibisyonuna yol açıp açmadığı incelenmiştir.

\section{Materyal ve Metot}

Materyal: Araştırma kapsamında yapılan farklı ekstraksiyon yöntemleri ve PCR uygulamalarında viral DNA daha önce tanısı ve filogenetik analizi gerçekleştirilmiş olan ülkemiz orjinli orf virus kabuk örneklerinden yapıldı (Akkutay-Yoldar ve ark., 2016). Kabuk materyali fosfat tamponlu sıvı çözeltisi (PBS) içinde homojenize hale getirildi. Homojenize materyal daha sonra -80 derecede 1 'er saat süreyle, üç kez dondurma-çözme işlemine tabi tutuldu. Bunu takiben de hücrelerden virusun PBS içerisine çıkmasını sağlamak amacıyla 4000 rpm de 15 dakika santrifüj edilerek DNA ekstraksiyonu için hazır hale getirildi.

DNA ekstraksiyonu: Viral DNA ekstraksiyonunda Sambrook ve Russell (2001) tarafından tanımlanan; konvansiyonel olarak adlandırdığımız asit guanidin tiyosiyanat-fenol ekstraksiyon metotu ve spin-kolon yöntemi ile çalışan 3 farklı nükleik asit kiti kullanıldı. Konvansiyonel ekstraksiyon metotunda $300 \mu$ l klinik örnek ve $300 \mu \mathrm{l}$ solüsyon D [4.2 M guanidin tiyosiyonat (Applichem A1107, Almanya), 0.75M sodyum sitrat dihidrat (Merck, Darmstadt, Almanya), $0.33 \mathrm{M} \mathrm{N}$-lauril sarcosin (Applichem, A1163, Almanya) ve $360 \mu \mathrm{l}$ 2-merkaptoetanol (Merck, Darmstadt, Almanya) bir araya getirildi ve 10-15 saniye vortekslendi. Karışımın üzerine $325 \mu \mathrm{l}$ alkali fenol ( $\mathrm{pH} 4)$, (Merck, Darmstadt, Almanya), $325 \mu \mathrm{l}$ kloroformizoamilalkol [Ch/IsoA (24:1)] eklendi ve homojen bir karışım elde edilene kadar 15 saniye süre ile vortekslendi. Tüpler, 12000 rpm de 10 dakika santrifüj edildi. Santrifüj sonunda oluşan 3 fazın en üst fazından $700 \mu$ yeni bir tüpe aktarıldı ve üzerine eşit hacimde $-20^{\circ} C^{\prime} y e$ soğutulmuş izopropanol (Merck, 1.09634.2500,
Darmstadt, Almanya) ve $100 \mu \mathrm{l} 3 \mathrm{M}$ sodyum asetat (pH 5.2) (Applichem, Almanya) ilave edildi ve karıştırıldı. Nükleik asit presipitasyonu için karışım en az 1 saat süre ile $-80^{\circ} \mathrm{C}$ de bekletildi. Süre sonunda oda Isısında eritildikten sonra, 14000 rpm'de 10 dakika santrifüj edildi. Çöken DNA pelleti, \%70' lik etanol (Sigma-Aldrich, 32221, Almanya) ile yıkandı ve $37^{\circ} \mathrm{C}^{\prime}$ lik etüvde kurutuldu. DNA pelletleri $20 \mu l$ deiyonize su ile yeniden süspanse edildi. Elde edilen DNA'lar PCR reaksiyonlarında kullanılmak amacıyla $-20^{\circ} \mathrm{C}^{\prime}$ de saklandı. Spin-kolon temelli ticari nükleik asit kitleri: QIAamp cador Pathogen Mini Kit (Qiagen), NucleoSpin RNA (Macherey-Nagel) ve The PureLink $^{\circledR}$ Viral RNA/DNA Mini Kit (Invitrogen), üreticilerin talimatlarına göre uygulandı.

PCR: Farklı kitlerle hazırlanan saf ve çeşitli ajanlara maruz bırakılan orf virusunun $B 2 L$ gen bölgesine spesifik PPP-1 (5'-GTCGTCCACGATGAGCAGCT-3') ve PPP-4 (5'-TACGTGGGAAGCGCCTCGCT-3') primerleri kullanılarak, Inoshima ve ark. (2000) tarafından bildirilen yöntem modifiye edilerek PCR reaksiyonları gerçekleştirildi (Inoshima ve ark. 2000). Biyo Güvenlik Kabini (BGK) (esco ıso 9001 quality, $A B D$ ) içerisinde hazırlanan PCR karışımı, 30 uL toplam hacim içinde ( $5 \mathrm{U} / \mu \mathrm{l})$ Taq DNA polimeraz (MBI, Fermentas, Waltham, MA, ABD), $10 \times$ Taq Tamponu (1.25 mL olup, (NH4) 2SO4 içeren), 25 $\mathrm{mmol} / \mathrm{L} \mathrm{MgCl} 2$ ve su (18 Mohm/cm, Applichem, Darmstadt, Almanya), primerler ve $3 \mu l$ ekstrakte edilmiş DNA kullanıldı. $96^{\circ} \mathrm{C}$ 'de 5 dakika süren ilk denatürasyonun ardından $96^{\circ} \mathrm{C}$ 'de 30 s DNA denatürasyonu, $48^{\circ} \mathrm{C}^{\prime}$ de 30 saniye primer bağlanma ve $72^{\circ} \mathrm{C}$ de 45 saniye amplifikasyon aşamalarını içeren 35 siklus gerçekleşti. PCR ürünleri etidyum bromid (Sigma-Aldrich, Almanya, 1:5000) içeren \%1 agaroz jelinde elektroforezden sonra transilluminatörde görüntülendi ve 595 bç büyüklüğündeki ürünler pozitif olarak değerlendirildi (Şekil 1). Elde edilen nükleik asitler hem ekstraksiyon sonrası hem de fizksel ve kimyasal ajanlara maruz kaldıktan sonra (Picodrop Microliter UV/Vis spektrofotometre (Picodrop, Cambridge, UK) ile ölçüldü (Tablo 1).

\section{Nükleik asitlere fiziksel ve kimyasal etkilerin uygulanması:}

Basınçlı buhar sterilizasyonu (Otoklav): Otoklavla sterilizasyon Systec D-90 (Systec GmbH, Switzerland) otoklav cihazında $121^{\circ} \mathrm{C}^{\prime}$ de $15 \mathrm{psi}$ basınçta, 15 dakika olarak gerçekleştirilmiştir.

Ultraviyole radyasyon: Ultraviyole ışınları, tepesine UV lambalarının monte edilmiş olduğu UV kutusunun içinde, $20 \mathrm{~cm}$ mesafeden; 30 dakika, 1 ve 4 saat olmak üzere 3 farklı süre boyunca DNA'ya uygulandı. 
Tween 20: Tween 20 (P1379 Sigma-Aldrich) diğer adıyla polyethylene glycol sorbitan monolaurate vizköz solüsyonu sulandırılmaksızın 1 damla olacak şekilde viral DNA üzerine tatbik edildi.

Tablo 1. Farklı yöntemler aracılığıyla elde edilen dsDNA'ların $(\mathrm{ng} / \mu \mathrm{l}) 260 \mathrm{~nm}$ dalga boyunda ölçümleri ve PCR sonuçları.

\begin{tabular}{|c|c|c|c|c|c|c|}
\hline \multirow[b]{2}{*}{ Ekstraksiyon Yöntemleri } & \multicolumn{5}{|c|}{ PCR sonuçları } & \multirow{2}{*}{$\begin{array}{l}\text { İzolasyon Sonrası DNA } \\
\text { miktarları ng/ml }\end{array}$} \\
\hline & Özellikler & $\begin{array}{l}\text { Direkt } \\
\text { PCR }\end{array}$ & Basınç & UV & Tween 20 & \\
\hline 1 QIAamp cador Pathogen & Viral RNA/DNA & + & + & - & - & 130.21 \\
\hline Mini Kit & Bakteriyel DNA & & & & & \\
\hline 2 NucleoSpin RNA & RNA & + & + & - & - & 58.10 \\
\hline 3 The PureLink & Viral RNA/DNA & + & + & - & - & 256.21 \\
\hline 4 Konvansiyonel & Viral DNA & + & + & - & - & 437.10 \\
\hline
\end{tabular}

\section{Bulgular}

PCR sonuçları konvansiyonel yöntemle elde edilen ekstraktlardan yapılan PCR'ın en yüksek amplifikasyona sahip olduğunu gösterdi. 1 ve 3 numaralı ticari kitler ile yapılan ekstraksiyonlar ideal bir pozitiflik verirken, 2 numaralı ekstraksiyon yönteminde ise diğer üç metota göre biraz daha zayıf bir pozitiflik elde edildi. Ekstraksiyon sonrası uygulanan ajanlardan tween 20, PCR'ın inhibisyonuna yol açmış olup, herhangi bir amplifikasyon gerçekleşmedi. Farklı sürelerde (30d, $1 \mathrm{~s}, 4 \mathrm{~s})$ uygulanan UV radyasyondan sonra da viral DNA tespit edilemedi. UV ışığa maruz kalınma

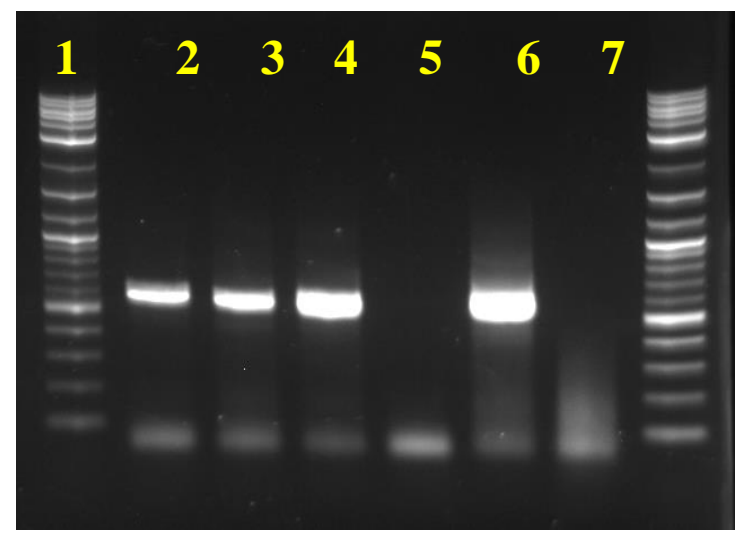

Şekil 1. Parapox virus B2L genine spesifik PCR sonucu oluşan ürünlerin agaroz jel görüntüsü. [1:3000 bp DNA merdiveni, 2: Macherey Nagel, 3: Cador, 4: Invitrogen, 5: negatif kontrol 6: Konvansiyonel, 7: negatif kontrol].

\section{Tartışma ve Sonuç}

Son yıllarda nükleik asit tespitine dayalı tekniklerin kullanılması önem arz etmektedir. Bu bağlamda nükleik asit elde edilmesinde, ticari kit kullanımı günümüzde oldukça tercih edilen ve zamanı kısaltan bir yol olmuştur. Bu ticari kitlerde kullanılan spin-kolon, sodyum katyonlarının DNA'ya bağlanması prensibinin temel alındığı bir metot olup, fenol-kloroform-izoamilalkol yönteminin toksik etkilerini minimalize etmektedir. Standardize edilmiş prosedürleri olan, minimum sonrası, yapılan dsDNA $260 \mathrm{~nm}$ dalga boyu spektrofotometre ölçümünde anlamlı bir veri elde edilememiş olmakla birlikte, ototklava maruz bırakılan ve tween 20 ile muamele edilen ekstraktların nükleik asit miktarlarının (ng/ $\mu \mathrm{l})$ spektrofotometre ölçüm sonuçları da daha önce elde edilen ekstraksiyon ölçümleriyle benzerlik göstermiş olup, herhangi bir ürün kaybı belirlenmedi. Fiziksel ajanlardan UV ve kimyasal ajan Tween 20'nin saf hali DNA'yı inhibe edebilir nitelikte olduğu görüldü. Otoklav işleminin ardından ise viral DNA güçlü bir şekilde amplifiye olmayı başardı (Şekil 2).

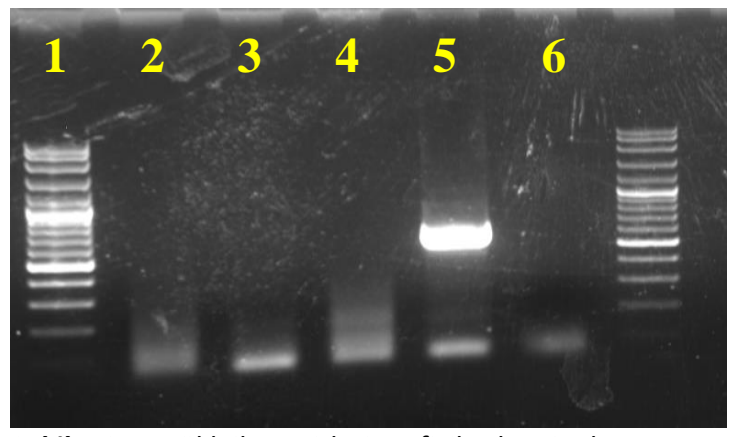

Şekil 2. Nükleik asitlerin fiziksel ajanlara maruz bırakılmalarının sonrası parapox virus B2L genine spesifik $P C R$ sonucu oluşan ürünlerin agaroz jel görüntüsü. [1:3000 bp DNA merdiveni, 2: UV radyasyonda 30 dakika bekletilen DNA, 3: UV radyasyonda 1 saat bekletilen DNA, 4: UV radyasyonda 4 saat bekletilen DNA, 5: Otoklav sonrası elde edilen DNA, 6: negatif kontrol].

kontaminasyonla yüksek verim elde eden bu ticari kitlerin yanı sıra, ultrafiltrasyon, magnetik küre, deterjan ve enzimlerle hücre zarını parçalayan birçok farklı ekstraksiyon yöntemi de konvansiyonel metoda alternatif olarak kullanılmaktadır (ChaconCortes ve Griffiths, 2014; Scherer ve ark., 2010).

Bu çalışmada, DNA verimliliği, PCR ürünü ve elde edilen ürünlerin çevre şartlarına dirençliliği üzerine odaklanıldı. Ayrıca farklı yöntemlerin DNA ekstraksiyon performansına etkilerinin değerlendirilmesi amaçlanarak bunlar karşılaştırıldı ve DNA miktarları spektrofotometrede (Picodrop, 
Cambridge, UK) ölçüldü. Kullanılan 1. kit tam kan, serum, sürüntü ve doku da dahil olmak üzere bir dizi hayvan örneğinden viral RNA, DNA ve bakteriyel DNA'nın izolasyonu amacıyla kullanılan bir kittir. Bu yöntem viral DNA izolasyonunda orta derecede bir verimlilik elde etmemizi sağladı. Denenen 2 . kit ise kolon içerisinde rDNase içeren ve kontamine DNA'nın kolay ve etkili bir şekilde uzaklaştırılmasını sağlayan bir yöntemdir. Bu yöntemde enzim varlığına rağmen ekstraksiyonunu yaptığımız virustan DNA izole etmeyi başardık fakat ürün verimliliği elde edilen diğer ürünlere göre daha düşük bulundu. 3 numaralı kit spin-kolon yöntemlerinin içerisinde en yüksek verimliliği veren ekstraksiyon kiti oldu. Taze veya donmuş plazma, serum, beyin-omurilik gibi sıvılardan ve hücre kültürü süpernatantlarından viral RNA ya da DNA eldesi sağlayan bu kit, konvansiyonel yöntemden sonra en yüksek verimliliği sağladı. Bunun nedeninin, kitin düşük elüsyon hacimleri kullanarak nükleik asiti pürifiye etmesi ve herhangi bir nükleaz içermemesinin etkili olduğu düşünüldü (Tablo 1 ). Spektrofotometre ds DNA ölçümlerine $(\mathrm{ng} / \mu \mathrm{l})$ ve agaroz jel görüntülerine bakıldığında en iyi sonuç veren ekstraksiyon metodu konvansiyonel yöntemdir. Asit guanidin tiyosiyanat-fenol temelli bu yöntem, maliyeti düşük ve spin-kolon yöntemlerine göre daha fazla zamana ihtiyaç duyulan bir uygulamadır. Spin-kolon yöntemlerinde sıklıkla etanolden kurtulmak için uygulanan iki aşamalı yıkama yönteminin bu uygulamada olmaması ürün kaybının daha az olmasında etkili bir faktör olabilir. Bu araştırmadaki beklenti ekstraksiyon kitlerinin manipülasyona bağlı meydana gelebilecek hataları indirgeyebileceği düşüncesinden hareketle, konvansiyonel metoda göre daha yüksek miktarda DNA elde edilmesiydi. Kazanılan bulgular ise DNA eldesinin konvansiyonel yöntemde daha yüksek olduğunu gösterdi. Birbirinden çok farklılık göstermemekle birlikte üç ticari kit de uygun miktarda DNA'yı izole etti.

Çalışmada basıncın viral DNA üzerindeki etkisine bakmak için örnekler basınçlı buhar otoklavına tabi tutulmuştur. Otoklav her ne kadar hücre yapısını parçalasa da viral genomların yok edilmesi için otoklavlamanın etkinliği hakkında çok az çalışma bulunmaktadır (Choi ve ark., 2014). Choi ve arkadaşlarının yaptığı çalışmada viral genomların, kuru şartlara göre hidratlı koşullarda daha kolay hasar gördüğü ve RNA virus genomunun, DNA virusundan daha kolay bozulduğu gözlemlenmiştir (Choi ve ark., 2014). Bu çalışmada elde edilen bulgular viral DNA amplifikasyonun otoklav sonrası kolaylıkla gerçekleştiğidir.

$\mathrm{Bu}$ çalışmada viral DNA üzerindeki etkisi araştırılan bir diğer fiziksel koşul olan ultraviyole radyasyon bir dezenfeksiyon yöntemi olarak laboratuvarlarda ve su dezenfeksiyonunda sıklıkla kullanılmaktadır. Bu araştırmada viral DNA, $20 \mathrm{~cm}$ gibi yakın bir mesafeden UV'ye maruz bırakılmış ve maruziyet süreleri olan 30 dakika, 1 ve 4 saat sonunda tekrar amplifiye olamamıştır. UV ışınlarının aracı bir yüzey olmadan direkt olarak ekstraksiyon ürününe ulaşması sağlanmıştır. DNA'nın ultraviyole radyasyona maruz kalması sonucunda oluşan lezyonlardan en çok gözleneni, pirimidin (6-4) pirimidon foto ürünleri ve oldukça mutajenik olan siklobütan pirimidin dimerleridir. Yapılan bir araştırmada ligasyon aracılı PCR yöntemleri ile bu lezyonların varlığı gösterilmiş ve nükleotid düzeyinde tespitleri gerçekleştirilmiştir (Besaratinia ve Pfeifer, 2012). UV radyasyon, tozsuz hava ve temiz su içinden kolaylıkla geçmesine rağmen; kire ve yağ tabakalarına, bulanık solüsyonlara ve plastik gibi maddelere etkin olarak geçemezler. Bu bağlamda moleküler düzeyde araştırmaların yapıldığı laboratuvarlarda UV radyasyonun direkt olarak uygulandığı yüzeyler DNA kontaminasyonun önlenmesinde etkin rol oynamaktadır. Yine de hücre kültüründe kendi genomunu tamir etme kabiliyetinde olan adenovirus gibi çift sarmallı DNA viruslarının UV dezenfeksiyonu daha zorlayıcıdır (Eischeid ve ark., 2009).

Polioksietilen (20) sorbitan monolaurat (tween 20), farmasötik formülasyonlar, gıda ve kozmetik endüstrilerinde bir emülsifiye edici ve stabilizatör olarak yaygın olarak kullanılan iyonik olmayan bir yüzey aktif maddedir (Eskandani ve ark., 2013). Bu çalışmada kimyasal ajan olarak kullanılan tween 20 ile viral DNA'ya yapılan işlem sonucunda PCR'da pozitiflik tespit edilemedi. Triton X-100, tween 20 gibi iyonik olmayan deterjanlar Taq polimeraz enzimini stabilize eder ve \%0.1-1'lik kullanımı verimi artırabilir. Bunun yanında istenmeyen nonspesifik amplifikasyon da artabilir (Bickley ve Hopkins, 1999). Tween 20 DNA ekstraksiyon metotlarında solüsyonların içerisinde ve PCR reaksiyonlarında mix içerisinde sulandırılarak kullanılan ve düşük düzeylerde bulunabilen bir ajan olmasına karşın bu çalışmada saf halde kullanılması viral DNA tespitine engel olmuştur (Xin ve ark., 2003).

Sonuç olarak viral DNA ekstraksiyonunda pek çok farklı ekstraksiyon kiti ve yöntem kullanılması viral DNA tespitine olanak sağlamaktadır. Bunlar içerisinde araştırılan yöntemlerden en yüksek verimliliğe sahip olanı konvansiyonel yöntem olarak tespit edildi. Ticari kitler ile konvansiyonel ekstraksiyon metotlarının da karşılaştırıldığı bu çalışma nükleik asit eldesi amacıyla konvansiyonel metotun sıklıkla tercih edilebilir olduğunu göstermiştir. Laboratuvara ulaşan örneklerden yüksek verimli DNA amplifikasyonu isteniyorsa viral DNA; UV radyasyon ve kimyasal ajanlara maruz bırakılmaması olumlu katkı sağlayacaktır. Elde 
edilen veriler ışığında, çalışmalarda, daha az zaman ve iş gücü gerektiren, tüm laboratuvarlarda standart olarak uygulanabilen ektraksiyon metotlarının tercih edilmesi önerilmektedir.

\section{Kaynaklar}

Akkutay-Yoldar Z, Oguzoglu TC, Akça Y, 2016: Diagnosis and phylogenetic analysis of orf virus in Aleppo and Saanen goats from an outbreak in Turkey. Virol Sin, 31(3), 270-273.

Arnal C, Ferre-Aubineau V, Besse B, Mignotte B, Schwartzbrod L, Billaudel S, 1999: Comparison of seven RNA extraction methods on stool and shellfish samples prior to hepatitis A virus amplification. J Virol Methods, 77(1), 17-26.

Besaratinia A, Pfeifer GP, 2012: Measuring the formation and repair of UV damage at the DNA sequence level by ligation-mediated PCR. In "DNA Repair Protocols", Ed; Bjergbaek, L, Humana Press, Totowa, NJ, pp. 189-202.

Bickley JA, Hopkins DA, 1999: Inhibitors and enhancers of PCR. In "Analytical Molecular Biology: quality and validation", Ed; Saunders GC and Parkers HC., pp.81102.

Chacon-Cortes D, Griffiths LR, 2014: Methods for extracting genomic DNA from whole blood samples: current perspectives. J Biorep Sci App Med, 2, 1-9.

Choi WS, Rodríguez RA, Sobsey MD, 2014: Persistence of viral genomes after autoclaving. I Virol Methods, 198, 37-40.

Deng MY, Wang H, Ward GB, Beckham TR, McKenna TS, 2005: Comparison of six RNA extraction methods for the detection of classical swine fever virus by realtime and conventional reverse transcription-PCR. $J$ Vet Diagn Invest, 17(6), 574-578.

Eischeid AC, Meyer JN, Linden KG, 2009: UV disinfection of adenoviruses: molecular indications of DNA damage efficiency. Appl Environ Microbiol, 75(1), 23-28.

Eskandani M, Hamishehkar H, Ezzati Nazhad Dolatabadi J, 2013: Cyto/Genotoxicity study of polyoxyethylene
(20) sorbitan monolaurate (tween 20). DNA Cell Biol, 32(9), 498-503.

Inoshima Y, Morooka A, Sentsui H, 2000: Detection and diagnosis of parapoxvirus by the polymerase chain reaction. J Virol Methods, 84, 201-208.

Knowles DP, 2011: Poxviridae. In "Fenner's Veterinary Virology", 4 ${ }^{\text {th }}$ Eds., Academic Press, Elsevier, Ed; N. Maclachlan N, Dubovi EJ, pp. 151-65.

Murphy FA, Gibbs EPJ, Horzinek MC, Studdert MJ, 1999: Veterinary Virology. Third ed. San Diego: Academic Press, pp. 335-342.

Reha-Krantz LJ, 2010: DNA polymerase proofreading: Multiple roles maintain genome stability. Biochimica et Biophysica Acta (BBA)-Proteins and Proteomics, 1804(5), 1049-1063.

Sambrook J, Russell DW, 2001: Molecular cloning: a laboratory manual. Cold Spring Harbor: Cold Spring Harbor Laboratory Press.

Scherer K, Johne R, Schrader C, Ellerbroek L, Schulenburg J, Klein G, 2010: Comparison of two extraction methods for viruses in food and application in a norovirus gastroenteritis outbreak. J Virol Methods, 169(1), 22-27.

Skinner MA, Buller RM, Damon IK, Lefkowitz EJ, McFadden G, Mc Innes CJ, Mercer AA, Moyer RW, Upton C, 2012: Poxviridae. In: Virus taxonomy: classification and nomenclature of viruses: Ninth Report of the International Committee on Taxonomy of Viruses. King AMQ, Adams MJ, Carstens EB, Lefkowitz EJ (Eds.), Elsevier Academic Press, San Diego, pp. 291-309.

Wilson IG, 1997: Inhibition and facilitation of nucleic acid amplification. Appl Environ Microbiol, 63(10), 3741.

Xin Z, Velten JP, Oliver MJ, Burke JJ, 2003: Highthroughput DNA extraction method suitable for PCR. Biotechniques, 34(4), 820-827.

Zimmer C, 2015: A planet of viruses. University of Chicago Press, pp. 1-30.

*Yazışma Adresi: Zeynep AKKUTAY-YOLDAR

Ankara Üniversitesi, Veteriner Fakültesi, Viroloji Anabilim Dalı, Dışkapı, 06110, Ankara, Türkiye.

E-mail: akkutay@ankara.edu.tr 